\title{
Study of the aetiology of wheezing illness at age 16 in two national British birth cohorts
}

Sarah Lewis, Barbara Butland, David Strachan, John Bynner, David Richards, Neville Butler, John Britton

Division of

Respiratory Medicine, University of Nottingham, City Hospital, Nottingham NG5 1PB, UK

$S$ Lewis

J Britton

Department of Public Health Sciences, St George's Hospital Medical School, Cranmer Terrace, London SW17 0RE B Butland

D Strachan

Social Statistics Research Unit, City University, Northampton Square, London EC1V 0HB

J Bynner

N Butler

Department of

Child Health,

University of

Nottingham

Queen's Medical

Centre,

Nottingham NG7 2UH,

UK

D Richards

Correspondence to: Sarah Lewis.

Received 2 October 1995 Returned to authors

Revised version received

27 December 1995

27 December 1995

11 January 1996

\begin{abstract}
Background - Data from two national British birth cohorts were used to measure the increase in prevalence of wheezing illness at age 16 between 1974 and 1986, and to investigate the role of several potential risk factors in the increase.

Methods - The occurrence of self-reported asthma or wheezy bronchitis within the past year, and the frequency of attacks of wheezing illness at age 16, were compared in 11262 and 9266 children born in one week of 1958 and 1970, respectively. The effects of several putative risk factors for asthma - including birth weight, maternal age, birth order, breast feeding, maternal smoking in pregnancy, child's personal smoking, and father's social class - on the change in occurrence of wheezing illness at age 16 were assessed by multiple logistic regression.
\end{abstract}

Results - The annual period prevalence of asthma or wheezy bronchitis at age 16 increased from $3.8 \%$ in 1974 to $6.5 \%$ in 1986 (prevalence ratio $(P R)=1 \cdot 71,95 \%$ CI 1.52 to $1 \cdot 93$ ). The proportion of children experiencing attacks more than once a week increased from $0.2 \%$ to $0.7 \%(P R=$ $3 \cdot 77,95 \%$ CI $2 \cdot 28$ to $6 \cdot 23$ ). The prevalence of self-reported eczema and hayfever within the past year doubled between 1974 and 1986, suggesting that the increase in asthma was part of a general increase in the prevalence of atopic disease. However, in the complete dataset, after adjustment for the effects of the risk factors studied, the prevalence odds ratio for asthma or wheezy bronchitis in 1986 compared with 1974 was virtually unchanged from the unadjusted value at $1.77(95 \%$ CI 1.46 to $2 \cdot 15)$. Conclusion - The prevalence of wheezing illness in British teenagers increased by approximately $70 \%$ between 1974 and 1986 . This increase appears to have occurred in the context of a general increase in atopic disease and was largely unexplained by changes in the distribution of maternal age, birth order, birth weight, infant feeding, maternal smoking, active smoking by the child, or father's social class.

(Thorax 1996;51:670-676)

Keywords: adolescent asthma, time trends, aetiology.

An increase in the prevalence of wheezing illness and diagnosed asthma has been reported in children and adults in the UK and in several other countries. ${ }^{1-9}$ The factors contributing to this increase are unknown, but increases in exposure to maternal cigarette smoke, an increased rate of survival of very low birth weight babies, an increase in bottle rather than breast feeding, an increasing proportion of children born to younger mothers, changes in air pollution levels, increased exposure to environmental allergen, and changes in dietary intake have all been implicated. ${ }^{10-14}$ To date, however, there have been few prospective population studies of the effects of these exposures.

We have used data on the prevalence of asthma or wheezy bronchitis at age 16 in two national British birth cohorts studied in 1974 and 1986 to determine whether asthma prevalence increased during this period in this age group, to determine whether the increase occurred in association with an increase in other atopic diseases, and to explore the roles of birth weight, maternal age, maternal smoking in pregnancy, breast feeding, birth order, father's social class, and teenage smoking in any change.

\section{Methods}

The 1958 and 1970 British birth cohorts, known respectively as the National Child Development Study (NCDS) and the British Cohort Study (BCS70), originated in studies of perinatal mortality amongst all children in England, Scotland and Wales born during one week of March 1958 and April 1970, respectively. The surviving children were followed up at ages seven, 11 , and 16 in the NCDS cohort, and at five, 10 , and 16 in the BCS70 cohort. In both cohorts, midwives collected information at birth on birth weight, father's occupational social class, ${ }^{15}$ maternal age, and maternal smoking during pregnancy, and at each subsequent follow up in both cohorts interviewers collected a wide range of social, family and health data from parents which included, at age 16 , data relating to the occurrence of wheezing and/or diagnosed asthma (appendix). In addition, the children in both cohorts provided details of personal current smoking at age 16 .

At age 16, parents were asked a question on wheezing illness which was worded virtually identically in both cohorts: "If your child ("teenager" in 1986) has had asthma or wheezy bronchitis in the past 12 months, did this occur at least once a week, usually less than once a week, less than once a month, or frequency unknown?", although it was differentially nested within previous questions. In both cases we have taken any positive response to the question on the occurrence of asthma and/or 
wheezy bronchitis at age 16 to indicate that the child had experienced symptoms of one of these wheezing illnesses in the past year at that age, and we have defined frequent wheeze as wheeze which occurred more than once a month. At age 16 , parents were also asked identical questions concerning absence from school for one week or more due to asthma or wheeziness in the past year, and the presence of hayfever or eczematous rashes in the past 12 months.

All analyses were carried out using SAS ${ }^{16}$ and SPSS-PC Version $4.1^{17}$ for univariate analyses within the 1958 and 1970 cohorts, respectively, and SAS and EGRET ${ }^{18}$ for multiple logistic regressions on the combined cohort. Potential bias in response at age 16 was investigated in both cohorts in relation to sex, father's social class at birth, and in children with and without a reported history of wheeze at previous follow ups. Where appropriate, estimates of prevalence were adjusted for differential response rates by combining the weighted prevalence estimates for each level of factors associated with response.

The potential risk factors investigated were birth weight, maternal age, father's social class, birth order, breast feeding, maternal smoking during pregnancy, and child's personal smoking. Details of maternal smoking in pregnancy were available for both cohorts as a derived categorical variable according to levels of cigarette consumption: $0,1-4,5-14$, and 15 or more cigarettes per day and, in 1958 only, an additional category defined as "variable smoking". In the derivation of a binary indicator of maternal smoking in pregnancy (ever versus never) a response in this latter category was taken to indicate smoking in pregnancy, and in dose-response analyses such a response was defined to be missing. The relationship between

Table 1 Summary of non-response bias at age 16, presented as the percentage responding to questions on asthma/wheezy bronchitis at age 16, by response to related questions at age 5 and 10 (1970 cohort) or 7 and 11 (1958 cohort)

\begin{tabular}{|c|c|c|c|c|}
\hline & \multicolumn{2}{|l|}{1958} & \multicolumn{2}{|l|}{1970} \\
\hline & Total & $\begin{array}{l}\text { Response to wheeze } \\
\text { question at age } 16\end{array}$ & Total & $\begin{array}{l}\text { Response to wheeze } \\
\text { question at age } 16\end{array}$ \\
\hline $\begin{array}{l}\text { Asthma/wheezy bronchitis ever by age } 7 \\
(1958) \text { and wheeze ever by age } 5(1970) \\
\text { Yes } \\
\text { No }\end{array}$ & $\begin{array}{r}2665 \\
11860\end{array}$ & $\begin{array}{l}(66 \%) \\
(68 \%)\end{array}$ & $\begin{array}{r}2703 \\
10274\end{array}$ & $\begin{array}{l}(58 \%) \\
(60 \%)\end{array}$ \\
\hline $\begin{array}{l}\text { Asthma/wheezy bronchitis in the past } \\
12 \text { months at age } 11(1958) \text { and wheeze } \\
\text { in past } 12 \text { months at age } 10 \text { (1970) } \\
\text { Yes } \\
\text { No }\end{array}$ & $\begin{array}{r}664 \\
12760\end{array}$ & $\begin{array}{l}(68 \%) \\
(71 \%)\end{array}$ & $\begin{array}{r}1045 \\
12599\end{array}$ & $\begin{array}{l}(59 \%) \\
(61 \%)\end{array}$ \\
\hline
\end{tabular}

Table 2 Comparison of prevalence of asthma or wheezy bronchitis and frequency of attacks in the past 12 months at age 16 in 1974 and 1986

\begin{tabular}{|c|c|c|c|c|c|}
\hline & \multicolumn{2}{|l|}{1974} & \multicolumn{2}{|l|}{1986} & \multirow{2}{*}{$\begin{array}{l}\text { Prevalence ratio } \\
(95 \% \text { CI })\end{array}$} \\
\hline & Total & Number (\%) & Total & Number (\%) & \\
\hline \multicolumn{6}{|l|}{ Asthma or wheezy bronchitis } \\
\hline $\begin{array}{l}\text { Total } \\
\text { Male } \\
\text { Female }\end{array}$ & $\begin{array}{r}11262 \\
5759 \\
5503\end{array}$ & $\begin{array}{l}427(3 \cdot 8 \%) \\
257(4 \cdot 5 \%) \\
170(3 \cdot 1 \%)\end{array}$ & $\begin{array}{l}9266 \\
4552 \\
4711\end{array}$ & $\begin{array}{l}601(6 \cdot 5 \%) \\
322(7 \cdot 1 \%) \\
279(5 \cdot 9 \%)\end{array}$ & $\begin{array}{l}1.71(1.52 \text { to } 1.93) \\
1.59(1.35 \text { to } 1.86) \\
1.92(1.59 \text { to } 2.31)\end{array}$ \\
\hline \multicolumn{6}{|c|}{ Frequency of attacks of asthma or wheezy bronchitis } \\
\hline $\begin{array}{l}\text { More than once a week } \\
\text { More than once a month } \\
\text { Less than once a month } \\
\text { Frequency unknown }\end{array}$ & 11262 & $\begin{array}{r}20(0 \cdot 2 \%) \\
41(0 \cdot 4 \%) \\
244(2 \cdot 2 \%) \\
122(1 \cdot 1 \%)\end{array}$ & 9266 & $\begin{array}{r}62(0 \cdot 7 \%) \\
43(0 \cdot 5 \%) \\
287(3 \cdot 1 \%) \\
209(2 \cdot 3 \%)\end{array}$ & $\begin{array}{l}3.77(2.28 \text { to } 6.23) \\
1.27(0.83 \text { to } 1.95) \\
1.43(1.21 \text { to } 1.69) \\
2.08(1.67 \text { to } 2.60)\end{array}$ \\
\hline
\end{tabular}

each of these factors and asthma and/or wheezy bronchitis in the past year, frequent wheeze, or school absence due to asthma/wheeziness were examined univariately within each cohort, and univariately between cohorts in the combined dataset after adjustment for a binary cohort term using multiple logistic regression. The cohort odds ratios (1986/1974) for asthma and/ or wheezy bronchitis in the past year were compared before and after adjustment for each risk factor, and the attributable risk calculated by the method of Breslow and Day. ${ }^{19}$ To investigate whether the relationship between each risk factor and disease prevalence was similar in 1986 to 1974 , each multiple logistic model was augmented with a term describing the statistical interaction between cohort and each risk factor.

Having examined the effects of individual risk factors, the combined effects of all risk factors were examined in a dataset restricted to those individuals with complete data on all of the aetiological factors investigated. The unadjusted odds ratio (1986/1974) for asthma and/or wheezy bronchitis in the past year was calculated as before, and then each of the factors birth weight, maternal age, father's social class, birth order, breast feeding, maternal smoking during pregnancy, and child's personal smoking at age 16 were added to the model to obtain the odds ratio adjusted for all of these risk factors in order to assess the proportion of the excess risk in 1986 which may be attributed to the overall change in exposure to these risk factors. Since the response rate to child's personal smoking was substantially lower, particularly in 1986, than for all other questions, the inclusion of child's smoking greatly reduced the size of the available dataset so further logistic regression models were fitted excluding child's personal cigarette consumption and the unadjusted and adjusted odds ratio examined as before.

Relationships between the other two measures of asthma - frequent wheeze and school absence due to asthma or wheeziness - and each of the aetiological variables were examined in a similar way.

\section{Results}

A response to the question concerning the occurrence of asthma and/or wheezy bronchitis was provided at age 16 by 11262 of the 1958 cohort in 1974 and 9266 of the 1970 cohort in 1986, whilst 11243 and 8592, respectively, provided information on school absence. In both cohorts the response rate at age 16 was independent of the wheezing history reported at previous follow ups (table 1) and, in 1974, response rates were consistent in males and females and across social class groups, but in 1986 males and the lowest social class groups were slightly under-represented. The response rates to the question on asthma/wheezy bronchitis for males and females in 1974 were $67 \%$ and $68 \%$ of those responding at age 7 , and in 1986 were $56 \%$ and $63 \%$, respectively of those responding at age 5 , and the response rate for those in non-manual compared with manual 
Table 3 Twelve month period prevalence of asthma/wheezy bronchitis at age 16 and prevalence ratios (1986/1974) for subjects with and without current hayfever and eczema

\begin{tabular}{|c|c|c|c|c|c|c|}
\hline \multirow{2}{*}{$\begin{array}{l}\text { Eczema in the } \\
\text { past } 12 \text { months }\end{array}$} & \multirow{2}{*}{$\begin{array}{l}\text { Hayfever in the } \\
\text { past } 12 \text { months }\end{array}$} & \multicolumn{2}{|l|}{1974} & \multicolumn{2}{|l|}{1986} & \multirow{2}{*}{$\begin{array}{l}\text { Prevalence ratio } \\
1986 / 1974 \\
(95 \% \mathrm{CI})\end{array}$} \\
\hline & & Total & $\begin{array}{l}\% \text { prevalence of asthma } \\
\text { and/or wheezy } \\
\text { bronchitis in the past } \\
12 \text { months at } 16\end{array}$ & Total & $\begin{array}{l}\% \text { prevalence of asthma } \\
\text { and/or wheezy } \\
\text { bronchitis in the past } \\
12 \text { months at } 16\end{array}$ & \\
\hline \multirow[t]{2}{*}{ No } & No & 9294 & $2 \cdot 5$ & 6659 & $3 \cdot 2$ & $1.27(1.06$ to 1.53$)$ \\
\hline & Yes & 1188 & $12 \cdot 1$ & 1858 & 14.9 & $1.23(1.02$ to 1.48$)$ \\
\hline Yes & $\begin{array}{l}\text { No } \\
\text { Yes }\end{array}$ & $\begin{array}{r}248 \\
93\end{array}$ & $\begin{array}{r}6 \cdot 0 \\
19 \cdot 4\end{array}$ & 347 & $\begin{array}{r}7 \cdot 5 \\
35 \cdot 1\end{array}$ & $1.24(0.67$ to 2.29$)$ \\
\hline
\end{tabular}

occupations were $69 \%$ and $68 \%$, respectively, in 1974 , and $63 \%$ and $58 \%$, respectively, in 1986. The lower response rate in males and those in manual occupations in 1986 was generally more marked in those with a wheezing history at age 5 or 10 .

The unadjusted period prevalence of reported asthma and/or wheezy bronchitis at age 16 increased from $3 \cdot 8 \%$ in 1974 to $6.5 \%$ in 1986 (prevalence ratio (PR) $1.71,95 \%$ confidence interval (CI) 1.52 to 1.93). This increase was slightly greater in females than in males (table 2) but was similar in all levels of father's social class. After adjustment for differential response according to sex and social class, in 1986 the period prevalence of asthma or wheezy bronchitis was $6.3 \%$ and the prevalence ratio adjusted for sex and social class effects for 1986 compared with 1974 was virtually unchanged at $1.67(95 \%$ CI 1.49 to $1 \cdot 87)$. The proportion of these children experiencing attacks more than once a week increased between 1974 and 1986 from $0 \cdot 2 \%$ to $0 \cdot 7 \%$ (PR = $3 \cdot 77,95 \%$ CI $2 \cdot 28$ to $6 \cdot 23$ ), but the proportion of children absent from school in the past year due to asthma or wheeziness increased to a lesser degree from $1.5 \%$ in 1974 to $1.7 \%$ in 1986 (PR $=1 \cdot 20,95 \%$ CI 0.96 to $1 \cdot 49$ ).

The reported period prevalence of eczema and hayfever doubled between 1974 and 1986, eczema from $3 \cdot 1 \%$ to $6 \cdot 4 \%$ (PR $2 \cdot 04,95 \%$ CI
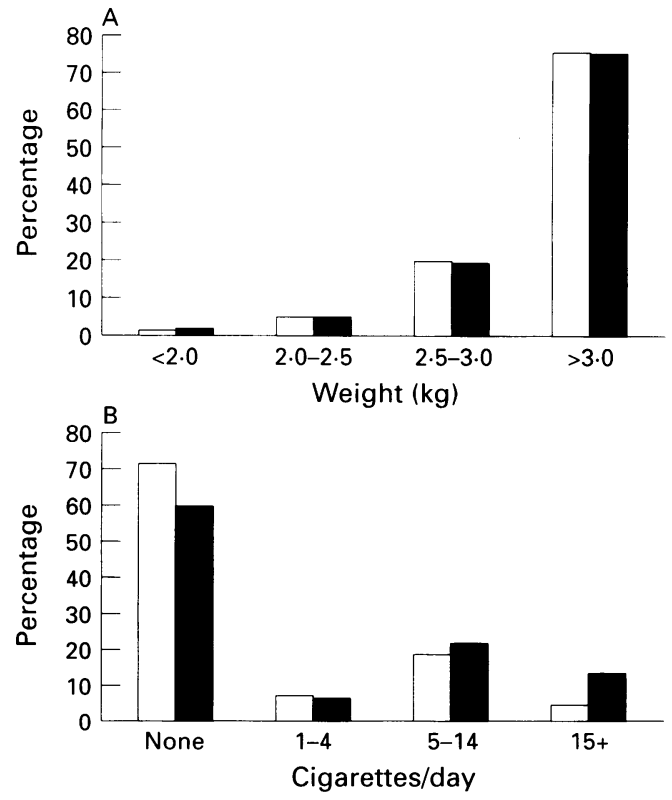

Figure 1 Distribution of $(A)$ birth weight and $(B)$ maternal smoking in pregnancy in the 1958 ( $\square$ ) and $1970(\mathbf{\square})$ birth cohorts.
1.79 to $2 \cdot 32$ ) and hayfever from $12 \cdot 0 \%$ to $23.3 \%$ (PR 1.93 , 95\% CI 1.82 to $2 \cdot 06$ ). The proportion of children reporting any one of asthma and/or wheezy bronchitis, hayfever or eczema also increased from $16.3 \%$ in 1974 to $29.0 \%$ in 1986 (PR $1.78,95 \%$ CI 1.69 to 1.88). Among children with eczema and/or hayfever the period prevalence of asthma and/or wheezy bronchitis increased by $36 \%$, compared with a $27 \%$ increase in those children with neither eczema nor hayfever, but this difference was not statistically significant $(p=0 \cdot 3)$. The greatest increase in asthma and/or wheezy bronchitis prevalence occurred in those children who were also reported to have both eczema ànd hayfever (PR $1 \cdot 82,95 \%$ CI $1 \cdot 16$ to $2 \cdot 85$, table 3 ), but there was also no significant difference between the prevalence ratios (1986/ 1974) for those children with both eczema and hayfever and those with only one or neither of these conditions $(p=0 \cdot 3)$.

Between the 1958 and 1970 cohorts there was a change in the distribution of several potential risk factors for asthma (figs 1, 2, and 3). In particular, there was a significant increase in the proportion of children with a birth weight under $2 \mathrm{~kg}(\mathrm{p}=0.001)$ and in the proportion of teenage mothers $(p<0.001)$. There was also a small but significant increase in the proportion of first born children $(p=0.01)$. Significantly more mothers reported smoking
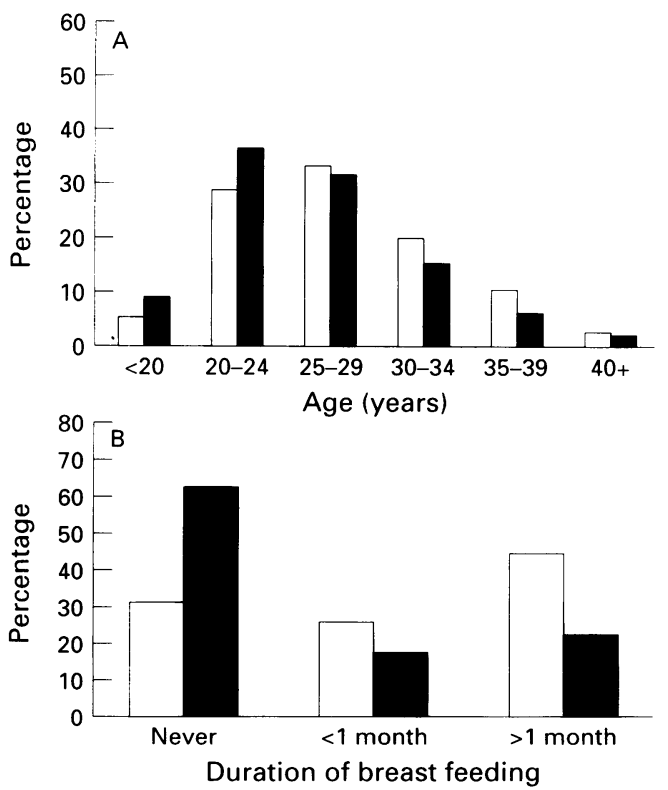

Figure 2 Distribution of $(A)$ maternal age and $(B)$ breast feeding in the $1958(\square)$ and 1970 ( $\square$ birth cohorts. 

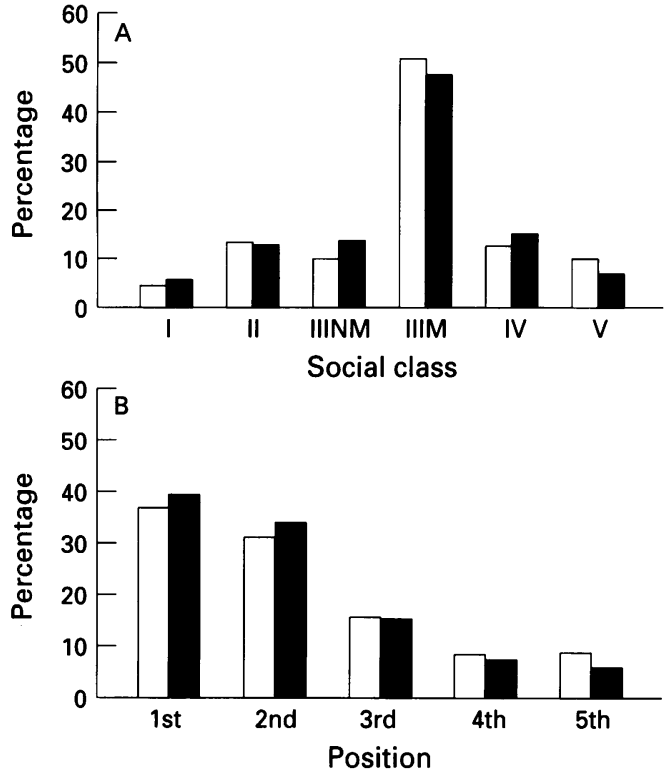

Figure 3 Distribution of $(A)$ father's social class and $(B)$ birth order in the $1958(\square)$ and 1970 (D) birth cohorts.

during pregnancy in 1970 than in 1958 $(p<0.001)$, with a significant trend towards higher cigarette consumption in 1970 $(p<0.001)$, and there was also a significant trend towards bottle feeding and bottle feeding at an earlier stage $(p<0.001)$. The proportion of children who reported personal smoking fell between 1974 and 1986 from $34.9 \%$ to $25 \cdot 8 \%$, and there was a significant trend towards lower cigarette consumption within smokers $(\mathrm{p}<0.001)$. In multiple logistic regression on the combined dataset, after adjustment for cohort, the occurrence of asthma and/or wheezy bronchitis at age 16 was inversely related to birth weight $\left(\chi^{2}\right.$ test for trend $\left.p<0.01\right)$ and to maternal age (table 4 ). There was a more complicated association with social class with the highest risk occurring in social class II, and also with maternal cigarette consumption during pregnancy where higher risks were associated with 1-4 and $15+$ cigarettes per day than with 5-14 per day. The occurrence of asthma and/or wheezy bronchitis was also related to the child's personal cigarette consumption with an odds ratio of 1.44 (95\% CI $1 \cdot 14$ to $1 \cdot 82$ ) associated with smoking at levels of $40+$ cigarette per week. There was no significant relationship between asthma and/or wheezy bronchitis at age 16 and duration of breast feeding, birth order or maternal smoking during pregnancy, expressed as a binary variable. There were no significant cohort and risk factor interactions. The odds ratios for asthma

Table 4 Comparison of the association between potential risk factors and asthma/wheezy bronchitis (A/WB) in the past year at age 16 in 1974 and 1986, with the odds ratios for each risk factor in the combined dataset after adjustment for cohort

\begin{tabular}{|c|c|c|c|c|c|c|c|}
\hline & \multicolumn{2}{|l|}{1974} & \multicolumn{2}{|l|}{1986} & \multirow{2}{*}{$\begin{array}{l}\text { Odds ratios in the } \\
\text { combined dataset }\end{array}$} & \multirow{2}{*}{$\begin{array}{l}\chi^{2} \text { test } \\
(d f)\end{array}$} & \multirow{2}{*}{$\begin{array}{l}\chi^{2} \text { test for trend } \\
(d f=1)\end{array}$} \\
\hline & Total & $\begin{array}{l}\text { Percentage } \\
\text { with } A / W B \\
\text { at age } 16\end{array}$ & Total & $\begin{array}{l}\text { Percentage } \\
\text { with } A / W B \\
\text { at age } 16\end{array}$ & & & \\
\hline $\begin{array}{l}\text { Birth weight }(\mathrm{kg}) \\
<2 \cdot 0 \\
2 \cdot 0-2 \cdot 5 \\
2 \cdot 5-3 \cdot 0 \\
>3 \cdot 0\end{array}$ & $\begin{array}{r}97 \\
500 \\
1979 \\
7708\end{array}$ & $\begin{array}{l}2 \cdot 1 \\
4 \cdot 8 \\
3 \cdot 9 \\
3 \cdot 7\end{array}$ & $\begin{array}{r}125 \\
414 \\
1623 \\
6389\end{array}$ & $\begin{array}{r}12 \cdot 0 \\
6 \cdot 8 \\
7 \cdot 9 \\
6 \cdot 0\end{array}$ & $\begin{array}{l}1 \cdot 00 \\
0 \cdot 77 \\
0 \cdot 78 \\
0 \cdot 64\end{array}$ & $\begin{array}{c}8 \cdot 76^{*} \\
(\mathrm{df}=3)\end{array}$ & $7 \cdot 77^{* *}$ \\
\hline $\begin{array}{l}\text { Maternal age } \\
<20 \\
20-24 \\
25-29 \\
30-34 \\
35-39 \\
40+\end{array}$ & $\begin{array}{r}572 \\
3065 \\
3530 \\
2119 \\
1075 \\
254\end{array}$ & $\begin{array}{l}4 \cdot 5 \\
4 \cdot 0 \\
3 \cdot 9 \\
3 \cdot 0 \\
4 \cdot 3 \\
3 \cdot 9\end{array}$ & $\begin{array}{r}764 \\
3091 \\
2700 \\
1267 \\
530 \\
160\end{array}$ & $\begin{array}{l}9 \cdot 2 \\
6 \cdot 1 \\
6 \cdot 9 \\
5 \cdot 8 \\
5 \cdot 3 \\
5 \cdot 0\end{array}$ & $\begin{array}{l}1 \cdot 00 \\
0.71 \\
0 \cdot 76 \\
0 \cdot 60 \\
0 \cdot 71 \\
0.65\end{array}$ & $\begin{array}{l}14 \cdot 34^{*} \\
(\mathrm{df}=5)\end{array}$ & $5 \cdot 42^{*}$ \\
\hline $\begin{array}{l}\text { Duration of breast feeding } \\
\text { Never breast fed } \\
<1 \text { month } \\
>1 \text { month }\end{array}$ & $\begin{array}{l}3055 \\
2438 \\
4327\end{array}$ & $\begin{array}{l}4 \cdot 2 \\
3 \cdot 4 \\
3 \cdot 6\end{array}$ & $\begin{array}{l}4766 \\
1281 \\
1661\end{array}$ & $\begin{array}{l}6 \cdot 5 \\
5 \cdot 2 \\
7 \cdot 5\end{array}$ & $\begin{array}{l}1 \cdot 00 \\
0 \cdot 82 \\
1 \cdot 00\end{array}$ & $\begin{array}{l}4 \cdot 98 \\
(\mathrm{df}=2)\end{array}$ & 0.02 \\
\hline $\begin{array}{l}\text { Maternal smoking in pregnan } \\
\text { None } \\
1-4 \\
5-14 \\
15+\end{array}$ & $\begin{array}{l}\text { cy (cigs/c } \\
7041 \\
699 \\
1778 \\
365\end{array}$ & $\begin{array}{r}\text { y) } \\
4 \cdot 0 \\
3 \cdot 0 \\
3 \cdot 3 \\
5 \cdot 5\end{array}$ & $\begin{array}{r}4942 \\
566 \\
1788 \\
1037\end{array}$ & $\begin{array}{l}6 \cdot 3 \\
8 \cdot 8 \\
5 \cdot 4 \\
7 \cdot 2\end{array}$ & $\begin{array}{l}1 \cdot 00 \\
1 \cdot 12 \\
0 \cdot 84 \\
1 \cdot 19\end{array}$ & $\begin{array}{l}8 \cdot 08^{*} \\
(\mathrm{df}=3)\end{array}$ & 0.008 \\
\hline $\begin{array}{l}\text { Child's smoking at age } 16 \text { (c) } \\
\text { None } \\
1-9(1-10) \\
10-19(11-20) \\
20-39(21-40) \\
40+(41+)\end{array}$ & $\begin{array}{l}\text { s/week) } \\
6026 \\
815 \\
441 \\
846 \\
1134\end{array}$ & $\begin{array}{l}1986 \text { categorie } \\
3 \cdot 4 \\
2 \cdot 9 \\
4 \cdot 1 \\
3 \cdot 5 \\
5 \cdot 2\end{array}$ & $\begin{array}{r}3630 \\
420 \\
190 \\
254 \\
396\end{array}$ & $\begin{array}{l}6 \cdot 4 \\
5 \cdot 7 \\
6 \cdot 8 \\
4 \cdot 3 \\
8 \cdot 1\end{array}$ & $\begin{array}{l}1 \cdot 00 \\
0.87 \\
1 \cdot 14 \\
0.90 \\
1.44\end{array}$ & $\begin{array}{l}11 \cdot 43^{*} \\
(\mathrm{df}=4)\end{array}$ & $4 \cdot 88^{*}$ \\
\hline $\begin{array}{l}\text { Birth order } \\
\quad 1 \text { (oldest) } \\
2 \\
3 \\
4 \\
5+\end{array}$ & $\begin{array}{r}3828 \\
3177 \\
1601 \\
827 \\
900\end{array}$ & $\begin{array}{l}3 \cdot 7 \\
4 \cdot 1 \\
3 \cdot 6 \\
4 \cdot 1 \\
4 \cdot 3\end{array}$ & $\begin{array}{r}3321 \\
2849 \\
1320 \\
598 \\
462\end{array}$ & $\begin{array}{l}6 \cdot 9 \\
5 \cdot 9 \\
6 \cdot 2 \\
7 \cdot 9 \\
6 \cdot 1\end{array}$ & $\begin{array}{l}1 \cdot 00 \\
0.95 \\
0.93 \\
1.13 \\
1 \cdot 01\end{array}$ & $\begin{array}{c}2 \cdot 40 \\
(\mathrm{df}=4)\end{array}$ & $0 \cdot 102$ \\
\hline $\begin{array}{l}\text { Father's social class as birth } \\
\text { I } \\
\text { II } \\
\text { IIINM } \\
\text { IIIM } \\
\text { IV } \\
\text { V }\end{array}$ & $\begin{array}{r}431 \\
1315 \\
1003 \\
5113 \\
1270 \\
982\end{array}$ & $\begin{array}{l}3 \cdot 0 \\
4 \cdot 8 \\
3 \cdot 7 \\
3 \cdot 4 \\
4 \cdot 4 \\
4 \cdot 1\end{array}$ & $\begin{array}{r}424 \\
1008 \\
1070 \\
3795 \\
1195 \\
494\end{array}$ & $\begin{array}{l}4 \cdot 7 \\
8 \cdot 1 \\
6 \cdot 1 \\
6 \cdot 0 \\
6 \cdot 4 \\
6 \cdot 5\end{array}$ & $\begin{array}{l}1 \cdot 00 \\
1 \cdot 72 \\
1 \cdot 28 \\
1 \cdot 22 \\
1 \cdot 42 \\
1 \cdot 40\end{array}$ & $\begin{array}{l}14 \cdot 61^{*} \\
(\mathrm{df}=5)\end{array}$ & $0 \cdot 16$ \\
\hline
\end{tabular}

${ }^{*} \mathrm{p}<0.05 ;{ }^{* *} \mathrm{p}<0 \cdot 01$ 
Table 5 Odds ratios for asthma prevalence at 16 (1970 cohort versus 1958 cohort), both unadjusted and adjusted for single potential risk factors

\begin{tabular}{llll}
\hline Potential risk factor & $\begin{array}{l}\text { Levels of factor } \\
\text { after recategorisation }\end{array}$ & $\begin{array}{l}\text { Odds ratio } \\
\text { unadjusted }\end{array}$ & $\begin{array}{l}\text { Odds ratio } \\
\text { adjusted }\end{array}$ \\
\hline Birth weight (kg) & 4 & $1 \cdot 77$ & $1 \cdot 77$ \\
Maternal age & 6 & $1 \cdot 75$ & 1.71 \\
Duration of breast feeding & 3 & 1.80 & $1 \cdot 78$ \\
Birth order & 5 & $1 \cdot 72$ & $1 \cdot 72$ \\
Maternal smoking in pregnancy & 4 & $1 \cdot 72$ & $1 \cdot 70$ \\
Child's smoking at age 16 & 5 & 1.79 & 1.82 \\
Father's social class & 6 & 1.71 & 1.71 \\
Sex & 2 & 1.76 & 1.77 \\
\hline
\end{tabular}

The unadjusted odds ratio is the odds ratio for asthma prevalence at 16 (1970 versus 1958 cohort) including only those children on whom information is also available for the relevant risk factor, and these differ between risk factors due to the differing numbers of children included. The adjusted odds ratio is the odds ratio for asthma prevalence at 16 (1970 versus 1958 cohort) after adjustment for the effect of the relevant risk factor.

and/or wheezy bronchitis at age 16 adjusted for any one of the potential risk factors were, however, little changed from the unadjusted value (table 5) and attributable risks for most of the risk factors examined were small, the largest being $4 \cdot 7 \%$ for maternal age. In the dataset of children with complete data for all risk factors $(n=10835)$ the unadjusted odds ratio for asthma and/or wheezy bronchitis in the past year at 16 for 1986 compared with 1974 was 1.75 (95\% CI 1.46 to $2 \cdot 09$ ). After adjustment for sex, birth weight, maternal age, breast feeding, birth order, smoking during pregnancy (expressed as a binary variable), father's social class at birth, and child's smoking at 16 (expressed as a binary variable), the odds ratio was virtually unchanged at 1.77 (95\% CI $1 \cdot 46$ to $2 \cdot 15$ ). Thus, after allowing for the change in disease prevalence which may be attributed to changes in any of these factors, there was an unexplained increase of approximately $77 \%$ in the prevalence of asthma and/or wheezy bronchitis in the past year. If child's smoking at 16 was excluded, the number of children with complete data increased to 15524 and the equivalent unadjusted and adjusted odds ratios were $1.72(95 \% \mathrm{CI} 1.49$ to 2.00$)$ and 1.67 (95\% CI 1.42 to 1.95$)$, respectively.

Only one significant association was apparent with the occurrence of frequent wheeze namely, a significant trend towards greater occurrence of frequent wheeze with increasing levels of maternal cigarette consumption during pregnancy (odds ratio (OR) for $15+$ cigarettes/ day $1 \cdot 89,95 \%$ CI $1 \cdot 16$ to $3 \cdot 06$ ). The attributable risk of frequent wheeze in relation to the increase in maternal smoking was $13 \%$. However, the odds ratio for frequent wheeze in 1986 compared with 1974 after adjustment for all risk factors was 2.25 (95\% CI 1.35 to $3 \cdot 78)$ and little changed from the unadjusted value of $2 \cdot 17$ (95\% CI $1 \cdot 35$ to $3 \cdot 50)$. Absence from school due to asthma or wheeziness was significantly related only to maternal cigarette consumption in pregnancy (OR for $15+$ cigarettes/day $=1 \cdot 63,95 \%$ CI $1 \cdot 12$ to $2 \cdot 37)$ and child's smoking at age $16(\mathrm{OR}=1.73$ for $40+$ cigarettes/day, $95 \%$ CI $1 \cdot 18$ to $2 \cdot 54$ ), but there was no significant increase in school absence due to asthma or wheeziness either before (unadjusted OR for 1986 compared with $1974=$ $1.07,95 \%$ CI 0.76 to 1.50 ) or after adjustment for all risk factors (adjusted $\mathrm{OR}=1 \cdot 16,95 \%$ CI 0.80 to $1 \cdot 67$ ).

\section{Discussion}

There is considerable evidence that wheezing in pre-teenage and teenage children has increased in prevalence over recent decades in a number of countries. In this study we have used data from two nationally representative British birth cohorts to establish whether the prevalence of wheezing illness in teenagers at age 16 increased between 1974 and 1986 in the UK, and to investigate for the first time the role of several potential aetiological factors in the increase. The prevalence of wheezing illness at age 16 increased by approximately $70 \%$, and there was a significant increase in the proportion of children with more frequent occurrence of symptoms. The increase in prevalence was most marked in those children with other expressions of atopy, but was largely unexplained by changing distributions of risk factors including maternal age, birth order, and smoking during pregnancy.

The 1958 and 1970 British birth cohorts provide a unique opportunity to study aetiological effects prospectively, since the samples studied are nationally representative and used very similar data collection methods. Both cohorts suffered inevitable loss to follow up at age 16 , and in the 1970 cohort this is particularly so in males and those in lower social class groups. Since the observed increase in prevalence was more marked in females, the overall prevalence rate in 1986 may have overestimated the true value. However, we found that there was no evidence that responders at age 16 in either cohort were more likely to have a previous history of wheezing, either within the population or within the under-represented groups, and that adjustment for differential response by sex and social class made little difference to the prevalence ratio between cohorts, so that no marked bias was, in fact, introduced.

The differential nesting of the asthma/wheezy bronchitis question in 1974 and 1986 and, in particular, the prior reference to "wheeze" in the latter cohort, is likely to have introduced some differential bias in response. Of the 601 who responded positively to the question on occurrence of asthma/wheezy bronchitis in $1986,485(81 \%)$ specifically stated in response to the prior question that the cause of the child's wheeze was either "asthma" or "wheezy bronchitis"; if the number of children with asthma or wheezy bronchitis in 1986 is restricted to those with one of these two responses to the prior question, the prevalence ratio for 1986 compared with 1974 is reduced but remains significant at $1 \cdot 38(95 \% \mathrm{CI} 1 \cdot 22$ to $1 \cdot 57)$. Furthermore, the 1974 question on asthma/ wheezy bronchitis was nested within a previous question asking when the most recent attack of asthma or wheezy bronchitis had occurred. If the number of children with asthma or wheezy bronchitis in 1986 is calculated as those who specify the cause of wheeze to be asthma or wheezy bronchitis and whose most recent attack of wheeze is reported to have been in the past 12 months, the prevalence ratio for asthma or wheezy bronchitis in 1986 compared with 1974 is reduced at $1.14(95 \%$ CI 1.00 to $1 \cdot 31, \mathrm{p}=0 \cdot 05)$. It is therefore possible, though 
unlikely, that the differential nesting of the questions in 1974 and 1986 wholly explains the observed increase.

The increase in asthma we observed for teenagers was rather greater in magnitude than estimates of the increase in younger children from other studies in the UK. ${ }^{49}$ It seems likely that part of the explanation for these increases in wheezing illness and frequency of symptoms, and for the small increase we have seen in time lost from school, is attributable to the increase in parental and teacher recognition and awareness of both symptoms and severity of asthma. It is recognised that the use of asthma as a diagnostic label has increased in recent years ${ }^{2021}$ but, in the present study, combining asthma and wheezy bronchitis will have reduced the effect of differential diagnosis of asthma or of diagnostic transfer from wheezy bronchitis to asthma. The consistency of the increase across all levels of social class and the substantial increase in reported frequency of symptoms provide more persuasive evidence for a real increase in wheezing illness. The small effect upon time lost from school may relate to the concurrent improvement in management of asthma over this time span. ${ }^{222}$

The apparent increase in teenage wheeze may be related to an increased tendency for the development of atopy, ${ }^{9}$ or to an increased susceptibility to wheeze as an expression of atopy. ${ }^{11}$ The expression of atopy measured in terms of allergen skin sensitivity or IgE levels increases during childhood to reach a peak in the early twenties, ${ }^{23}$ and recent evidence that wheezing that occurs at age 16 is aetiologically distinct from early childhood wheezing suggests that wheeze in this age group may be more likely to be a manifestation of atopy than of effects attributable to passive smoke exposure or airway size. ${ }^{24}$ Since skin test and IgE serum levels are not available for the 1970 cohort, we are unable to determine whether the increase in prevalence of wheeze was due to an increase in occurrence of atopy, but we have addressed this question by analysing parental reporting of eczema and hayfever - two atopic conditions which may be more easily recognised by parents than symptoms of asthma - as a marker of childhood atopy. We found a twofold increase in the period prevalence at age 16 of both conditions, suggesting that a general rise in the occurrence of allergic disease in teenagers occurred between 1974 and 1986. We also found that, although not significantly so, the increase in asthma or wheezy bronchitis was more marked in those children with other atopic disease. Thus, it appears that the large increase we have observed in teenage wheezing is a manifestation of a general increase in expression of atopic disease, and to an increased tendency to the development of wheeze within atopic children. Our findings are consistent with evidence from Australia of an increase in the occurrence of airways hyperreactivity in atopic children which suggests that wheeze may be becoming a more common expression of atopy. ${ }^{11}$

Changes in genetic susceptibility to atopy, or to wheezing as a response to atopy, are unlikely to have occurred over the 12 year period between 1974 and 1986, and a more probable explanation is that the increase is due to a change in exposure to environmental determinants of asthma, or to environmental factors which promote allergy or wheezing as an expression of allergy in a susceptible child. The onset of most childhood wheezing occurs in infancy, ${ }^{2526}$ and it has been suggested that in utero and early life exposures are important in both the development of symptoms in early life, the persistence of wheeze into adolescence, and the occurrence of reduced lung function and chronic obstructive airways disease in later life, ${ }^{27}$ since wheezing in early childhood is strongly associated independently with maternal smoking, particularly during pregnancy, ${ }^{2829}$ and low birth weight. ${ }^{1224}$ Low maternal age has been shown to be related to asthma in adolescence $^{30}$ and the number of older siblings in the house may be inversely related to development of atopy and allergic disease, ${ }^{3132}$ though these two effects are correlated. There is also conflicting evidence that breast feeding may protect against respiratory infection in infancy and subsequent development of atopic disease. $^{33}$

Of the risk factors we investigated, the only significant determinant of asthma or wheezy bronchitis in either cohort which changed sufficiently in distribution between 1974 and 1986 to explain more than a negligible proportion of the observed increase was low maternal age. The proportions of teenage mothers in 1974 and 1986 were $5.4 \%$ and $9.0 \%$, respectively, consistent with Office of Population Census and Surveys (OPCS) published figures for the proportion of teenage mothers in the UK in 1958 and 1970 of $5.9 \%$ and $10.3 \%$, respectively, and suggesting an increase of $67 \%$. However, the effect of maternal age is small and, as a consequence, whether modelled as a categorical or continuous variable, the changing pattern of maternal age was responsible for no more than an estimated $5 \%$ of the increase in teenage wheezing illness.

Although OPCS published figures indicate that the prevalence of smoking has fallen in recent years in many sectors of the population, both OPCS and cohort data demonstrate that smoking in younger women was still increasing during this period, from $32.9 \%$ to $41 \cdot 9 \%$. $^{34}$ There is considerable evidence that maternal smoking - particularly during pregnancy and in the early life of the child - is associated with wheezing in early childhood, ${ }^{2829}$ and that exposure to cigarette smoke very early in life may increase a child's susceptibility to the development of atopic disease and to more severe expression of atopy in the child. ${ }^{35}$ However, our findings suggest a weaker relationship between wheezing in adolescence and maternal passive smoking which was not dose-related, and the increase in teenage wheezing illness which could be attributed to maternal smoking in pregnancy was only $2 \cdot 5 \%$. High levels of maternal cigarette consumption during pregnancy were associated with an increased risk of frequent asthma symptoms, and while the effect 
of maternal smoking may be more likely to occur in relation to current passive smoke exposure at age $16,13 \%$ of the considerable increase in frequent symptoms may be attributable to the increase in maternal smoking. However, in both the 1958 and 1970 cohorts maternal smoking in pregnancy was a much stronger predictor of wheezing in early childhood. We were unable to compare the prevalence of wheeze between the cohorts in earlier years due to incomparability of respiratory questions, but it remains important to assess whether the changes we have observed in maternal smoking have contributed to the reported concurrent increase in early childhood wheezing illness.

Our finding that fewer teenagers were smoking, and smoking heavily, in 1986 than in 1974 is consistent with OPCS national data which suggest that, between 1974 and 1986 , teenage smoking reduced from $40 \%$ to $30 \%$. There was a much reduced response rate to the smoking question in 1986, particularly in males (response rate for males and females of $31.8 \%$ and $46.0 \%$, respectively, of those who responded at age 5), which is likely to cause a systematic underestimate of the effect of personal smoking and, in the combined cohort, an increase in wheeze outcomes was associated with high levels of smoking only. Smoking in adolescence may be associated with the onset of a range of respiratory symptoms ${ }^{36}$ and the reduction in prevalence and intensity of cigarette smoking among teenagers may have been one factor limiting the increase in prevalence between cohorts.

Thus, the present study has suggested a substantial increase in the prevalence of wheezing illness in teenagers in the UK, and has established that several factors previously implicated were not major contributors to the observed increase. Future studies are required to investigate the contribution of changes over time in other potential aetiological factors including levels of outdoor and indoor pollutant exposure, allergen exposure, and diet.

The authors thank the Economic and Social Research Counci Data Archive, University of Essex as the source of the 1958 data, and the National Birthday Trust, University of Bristol and the International Centre for Child Studies (ICCS) a the source of the 1970 data. We thank the National Asthm Campaign for funding the analyses presented in this study.

\section{Appendix}

Comparison of the cohort respiratory questions in 1974 and 1986

\begin{tabular}{|c|c|}
\hline 1974 & 1986 \\
\hline \multirow[t]{2}{*}{$\begin{array}{l}\text { Has the study child every had an attack of } \\
\text { asthma or wheezy bronchitis? }\end{array}$} & $\begin{array}{l}\text { Has the study child ever had an attack of } \\
\text { wheezing or whistling in the chest? }\end{array}$ \\
\hline & $\begin{array}{l}\text { What were these thought to be due to? } \\
\text { Asthma } \\
\text { Wheezy bronchitis } \\
\text { Other cause }\end{array}$ \\
\hline $\begin{array}{l}\text { Did the most recent attack occur: } \\
\text { In the past } 12 \text { months? }\end{array}$ & $\begin{array}{l}\text { When did the most recent attacks occur: } \\
\text { In the past } 12 \text { months? }\end{array}$ \\
\hline $\begin{array}{l}\text { If the child has had asthma or wheezy } \\
\text { bronchitis in the past } 12 \text { months did this } \\
\text { occur: } \\
\text { At least once a week } \\
\text { Usually less than once a week } \\
\text { Less than once a month } \\
\text { Frequency unknown }\end{array}$ & $\begin{array}{l}\text { If the teenager has had asthma or wheezy } \\
\text { bronchitis in the past } 12 \text { months, did this } \\
\text { occur: } \\
\text { At least once a week } \\
\text { Usually less than once a week } \\
\text { Less than once a month } \\
\text { Frequency unknown }\end{array}$ \\
\hline
\end{tabular}

1 Anderson HR. Is asthma really increasing? Paediatr Respir Med 1993;1:6-10.

2 Anderson HR, Butland BK, Strachan DP. Trends in the prevalence and severity of childhood asthma. BMF 1994; 308:1600-4.

3 Burney PGJ, Chinn S, Rona RJ. Has the prevalence of asthma increased in children? Evidence from the national study of health and growth 1973-86. BMF 1990;300: 1306-10.

4 Burr ML, Butland BK, King S, Vaughan-Williams E. Changes in asthma prevalence: two surveys 15 years apart. Arch Dis Child 1989;64:1452-6.

5 Gergen PJ, Mullally DI, Evans R. National survey of prevalence of asthma among children in the United States, 1976 to 1980 . Pediatrics $1988 ; 81: 1-7$.

6 Mitchell EA. Increasing prevalence of asthma in children. $N Z$ Med f 1983;96:463-4.

7 Hsieh K-H, Shen J-J. Prevalence of childhood asthma in Taipei, Taiwan, and other Asian Pacific countries. $\mathcal{F}$ Asthma 1988;25:73-82.

8 Britton JR. Asthma's changing prevalence. BMF 1992;304: $857-8$

9 Ninan TK, Russell G. Respiratory symptoms and atopy in Aberdeen school children: evidence from two surveys 25 years apart. BMf 1992;304:873-5.

10 Seaton A, Godden DJ, Brown K. Increase in asthma: a more toxic environment or a more susceptible population? Thorax 1994;49:171-4.

11 Peat JK, van den Berg RH, Green WF, Mellis CM, Leeder $\mathrm{SR}$. Changing prevalence of asthma in Australian children. SR. Changing prevalence

12 Seidman DS, Laor A, Gale R, Stevenson DK, Danon YL. Is low birth weight a risk factor for asthma during adolescence. Arch Dis Child 1991;66:584-7.

13 Schwartz J, Gold D, Dockery DW, Weiss ST, Speizer FE. Predictors of asthma and persistent wheeze in a national sample of children in the United States. Am Rev Respir Dis 1990;142:555-62.

14 Burr ML. Epidemiology of asthma. Epidemiol Clin Allergy 1993;31:80-102.

15 Registrar General of England and Wales. Classification of occupations. London: HMSO, 1966.

16 SAS Institute. SAS users' guide: basics and statistics. Version 5. Cary, North Carolina: SAS Institute, 1985.

17 Norusis MJ/SPSS Inc. SPSS/PC + 4. Base Manual. Chicago: SPSS Inc., 1990.

18 Statistics and Epidemiology Research Corporation. EGRET. Seattle: SERC, 1988.

19 Breslow NE, Day NE. In: Davis W, ed. Statistical methods in cancer research. Volume 1: The analysis of case-control studies. Lyon: International Agency for Research on Cancer studies. Lyon: International Agency for Research on C

20 Hill R. Change in use of asthma as a diagnostic label for wheezing illness in schoolchildren. BMF 1989;299:898.

21 Whallett EJ, Ayres JG. Labelling shift from acute bronchitis may be contributing to the recent rise in asthma mortality in the 5-34 age group. Respir Med 1993;87:183-6.

22 Hay IFC, Higenbottam TW. Has the management of asthma improved? Lancet 1987;ii:609-11.

23 Barbee RA, Brown WG, Kaltenborn W, Halonen M. Allergen skin-test reactivity in a community population sample: correlation with age, histamine skin reactions, and total serum relation with age, histamine skin reactions, and total serum
immunoglobulin. 7 Allergy Clin Immunol 1981;68:15-9.

24 Lewis S, Richards D, Bynner J, Butler N, Britton J. The aetiology of wheezing illness in childhood and adolescence: a prospective study of the independent effects of passive smoking, birth weight, maternal age, and socio-economic status. Eur Respir $\mathcal{F}$ 1995;8:349-56.

25 Strachan DP. The prevalence and natural history of wheezing in early childhood. $₹ \mathcal{R}$ Coll Gen Pract 1985;35:182-4.

26 Luyt DK, Burton PR, Simpson H. Epidemiological study of wheeze, doctor diagnosed asthma, and cough in preschool wheeze, doctor diagnosed asthma, and cough in preschoc

27 Barker DJP, Godfrey KM, Osmond C, Winter PD, Shaheen SO. Relation of birth weight and childhood respiratory infection to adult lung function and death from chronic obstructive airways disease. $B M \mathcal{F}$ 1991;303:671-5.

28 Tager IB, Hanrahan JP, Tosteson TD, Castile RG, Brown RW, Weiss ST, et al. Lung function, pre- and post-nata smoke exposure, and wheezing in the first year of life. $A m$ Rev Respir Dis 1993;147:811-7.

29 Taylor B, Wadsworth J. Maternal smoking during pregnancy and lower respiratory tract illness in early life. Arch Dis Child 1987;62:786-91.

30 Anderson HR, Bland JM, Patel S, Peckham C. The natural history of asthma in childhood. $\mathcal{f}$ Epidemiol Community history of asthma in chilh $1986 ; 40: 121-9$.

31 von Mutius E, Martinez FD, Fritzsch C, Nicolai T, Reitmeir $P$, Thiemann $\mathbf{H}-\mathrm{H}$. Skin test reactivity and number of P, Thiemann H-H. Skin test
siblings. $B M \mathcal{F}$ 1994;308:692-6.

32 Strachan DP. Hay fever, hygiene, and household size. $B M \mathcal{Y}$ 1989;299:1259-60.

33 Chandra RK, Puri S, Cheema PS. Predictive value of cord blood IgE in the development of atopic disease and role of breast feeding in its prevention. Clin Allergy 1985;15:517-22.

34 Wald N, Kiryluk S, Darby S, Doll R, Pike M, Peto R. UK smoking statistics. Oxford: Oxford University Press, 1988 34-5.

35 Arshad SH, Hide DW. Effect of environmental factors on the development of allergic disorders in infancy. $\mathcal{f}$ Allergy Clin Immunol 1992;90:235-41.

36 Adams L, Lonsdale D, Robinson M, Rawbone R. Respiratory impairment induced by smoking in children in secondary schools. BMF 1984;288:891. 